Article

\title{
Modification of nanocrystalline HZSM-5 zeolite with tetrapropylammonium hydroxide and its catalytic performance in methanol to gasoline reaction
}

\author{
HE Yingping a , LIU Min a,*, DAI Chengyi a , XU Shutao ${ }^{b}$, WEI Yingxu ${ }^{b}$, LIU Zhongmin ${ }^{b}$, GUO Xinwen ${ }^{a, \#}$ \\ a State Key Laboratory of Fine Chemicals, Department of Catalysis Chemistry and Engineering, School of Chemical Engineering, Dalian University of \\ Technology, Dalian 116024, Liaoning, China \\ ${ }^{\mathrm{b}}$ Dalian Institute of Chemical Physics, Chinese Academy of Sciences, Dalian 116023, Liaoning, China
}

\section{A R T I C L E I N F O}

Article history:

Received 30 November 2012

Accepted 18 March 2013

Published 20 June 2013

\section{Keywords:}

Nanocrystalline HZSM-5

Zeolite

Tetrapropylammonium hydroxide

Methanol to gasoline
A B S T R A C T

Nanocrystalline ZSM-5 zeolite was modified with tetrapropylammonium hydroxide (TPAOH) solution. The effect of the TPAOH treatment time on the catalytic performance of HZSM-5 was investigated in methanol to gasoline (MTG) reaction. The modified samples were characterized using X-ray diffraction, scanning electron microscopy, ${ }^{27} \mathrm{Al}$ and ${ }^{29} \mathrm{Si}$ magic-angle spinning nuclear magnetic resonance spectroscopy, X-ray photoelectron spectroscopy, $\mathrm{N}_{2}$ adsorption, and $\mathrm{NH}_{3}$ temperature-programmed desorption. The HZSM-5 structure was basically unchanged after modification, but the relative crystallinity increased and the crystal morphology was more regular. The Brunauer-Emmett-Teller surface area, the micropore surface area, the surface $\mathrm{Si} / \mathrm{Al}$ ratio, and the amount of strong acid sites increased; this might be caused by desilication and dealumination, and secondary crystallization of the zeolite during the treatment. The stability of the catalyst was significantly improved after modification, as reflected by the increased lifetime from $70 \mathrm{~h}$ to above $170 \mathrm{~h}$ in MTG reaction. The catalyst lifetime increased with increasing TPAOH treatment time. Hydrogen transfer reactions became faster and led to more isoparaffins and less olefins in the liquid products.

(C) 2013, Dalian Institute of Chemical Physics, Chinese Academy of Sciences. Published by Elsevier B.V. All rights reserved.

\section{Introduction}

The methanol to gasoline (MTG) process [1-3] was first discovered and developed by researchers at Mobil in 1976, based on coal or natural gas as the raw material and conversion of synthesis gas to methanol. In the MTG process, crude methanol is transformed into high-octane and high-quality gasoline, which contains no sulfur, chlorine, or other impurities and has a good anti-knock performance. With the shortage of world oil resources and the overproduction of domestic methanol, methanol is becoming a new source of fossil-fuel raw materials.

ZSM-5 zeolite is usually used as the catalyst in the MTG process. The ZSM-5 zeolite framework contains two interconnected pore systems, i.e., straight channels $(0.51 \mathrm{~nm} \times 0.55 \mathrm{~nm})$ and zigzag channels $(0.53 \mathrm{~nm} \times 0.56 \mathrm{~nm})$, creating a three-dimensional network. The presence of micropores gives rise to the use of zeolites as shape-selective catalysts. In ZSM-5, diffusion of molecules that have a greater critical size than that of durene is difficult, leading to high selectivity in MTG. However, the stability of the parent HZSM-5 is not satisfactory be-

\footnotetext{
*Corresponding author. Tel/Fax: +86-411-84986134; E-mail: lium@dlut.edu.cn

\# Corresponding author. Tel/Fax: +86-411-84986133; E-mail: guoxw@dlut.edu.cn

This work was supported by the New Century Excellent Talent in University, China (NCET-04-0268) and the Plan 111 Project of the Ministry of Education of China.
} 
cause of easy coke deposition on the strong acid sites on the surface [4]. It is therefore important to improve the catalyst stability.

Alkaline modification, i.e., desilication by treatment in an alkaline medium, is a very suitable and reproducible method for obtaining mesoporous ZSM-5 zeolites with improved diffusivity and catalytic cracking ability, and has attracted growing interest in zeolite applications in recent years. Currently, an inorganic $\mathrm{NaOH}$ solution is generally used as the alkaline medium. Bjørgen et al. [5] reported a significant improvement in the catalyst lifetime and a strongly enhanced selectivity towards the desired gasoline fraction, i.e., more aromatic and paraffinic compounds in the products, for HZSM-5 samples treated with $\mathrm{NaOH}$ solution. The results were rationalized by the development of acidity, improved crystallinity, and mesopore formation. Ogura et al. [6] and Suzuki et al. [7] found changes in the adsorption curves and pore size distributions for MFI zeolites modified with $\mathrm{NaOH}$ solution, leading to increased catalytic activity. Groen et al. [8,9] reported the formation of accessible intracrystalline mesopores in HZSM-5 as a result of selective removal of framework silicon by controlled desilication with $\mathrm{NaOH}$. Ni et al. [10] prepared a hierarchical mesoporous $\mathrm{Zn} / \mathrm{ZSM}-5$ zeolite catalyst by $\mathrm{NaOH}$ treatment and $\mathrm{Zn}$ impregnation, giving significant improvements in the catalyst lifetime and liquid hydrocarbon yield in the MTG reaction. Xiao et al. [11] studied $\mathrm{NaOH}$-treated mordenite containing a template and obtained increased isobutene conversion for ethyl tert-butyl ether synthesis. At present, organic alkaline treatment is usually used for TS-1. Compared with inorganic alkaline treatments, organic alkaline treatments give more moderate modifications and are more easily controlled. Mao et al. [12] found that the structure of TS- 1 was basically unchanged after modification with tetrapropylammonium hydroxide (TPAOH) solution, but internal corrosion occurred. The modified sample showed a significant improvement in catalytic performance in the hydroxylation of phenol and ammoxidation of methyl ethyl ketone. Xia [13] studied TPAOH-treated TS-1 and observed an improved performance in the ammoxidation of methyl ethyl ketone. To date, few organic alkaline modifications of ZSM-5 zeolites have been reported.

In this work, we modified nanocrystalline ZSM-5 zeolite by TPAOH treatment and investigated its catalytic performance in MTG reaction and its physical and chemical properties.

\section{Experimental}

\subsection{Catalyst preparation}

Nanocrystalline NaZSM-5 zeolite powder $\left(\mathrm{SiO}_{2} / \mathrm{Al}_{2} \mathrm{O}_{3}\right.$ molar ratio $=26$, crystal size $70-100 \mathrm{~nm}$ ), synthesized using the patented method [14], was treated with $0.1 \mathrm{~mol} / \mathrm{L}$ TPAOH solution for 24,48 , or $72 \mathrm{~h}$ at $170{ }^{\circ} \mathrm{C}$ in an autoclave, followed by washing with deionized water and filtering. After drying and calcination, the samples were ion exchanged three times with $0.4 \mathrm{~mol} / \mathrm{L} \mathrm{NH}_{4} \mathrm{NO}_{3}$ solution for $2 \mathrm{~h}$ at $75^{\circ} \mathrm{C}$, followed by washing, filtering, drying at $100{ }^{\circ} \mathrm{C}$, and calcination in static air at $540{ }^{\circ} \mathrm{C}$ for $4 \mathrm{~h}$. The obtained TPAOH-treated nanocrystalline
HZSM-5 samples were designated HZ (no treatment), T24-HZ (treated for $24 \mathrm{~h}$ ), T48-HZ (treated for $48 \mathrm{~h}$ ), and T72-HZ (treated for $72 \mathrm{~h}$ ). Strips of the TPAOH-treated nanocrystalline HZSM-5 samples were obtained by extruding mixtures of the TPAOH-treated nanocrystalline HZSM-5 samples with alumina (weight ratio of $\mathrm{HZSM}-5: \mathrm{Al}_{2} \mathrm{O}_{3}=4: 1$ ), followed by washing, drying at $100{ }^{\circ} \mathrm{C}$, and calcination in static air at $540{ }^{\circ} \mathrm{C}$ for $4 \mathrm{~h}$. The obtained samples were designated nHZ, T24, T48, and T72.

\subsection{Catalyst characterization}

X-ray diffraction (XRD) patterns were recorded using a Rigaku D/max-2400 diffractometer at a scanning rate of $6^{\circ} / \mathrm{min}$ from $5^{\circ}$ to $50^{\circ}$. The crystal sizes and morphologies of the samples were examined using scanning electron microscopy (SEM; JEOL JSM-5600 LV). ${ }^{27} \mathrm{Al}$ and ${ }^{29} \mathrm{Si}$ magic-angle spinning nuclear magnetic resonance (MAS NMR) spectra were recorded using a Bruker Avance III 600 spectrometer. ${ }^{27} \mathrm{Al}$ MAS NMR spectra were recorded at a resonance frequency of 156.4 $\mathrm{MHz}$ with a spinning rate of $12 \mathrm{kHz}$, using a $0.75 \mu \mathrm{s}(\pi / 8)$ pulse with a 2 s recycle delay; chemical shifts were referenced to 3-(trimethylsilyl)-1-propanesulfonic acid sodium salt. ${ }^{29}$ Si MAS NMR spectra were recorded at a resonance frequency of 119.2 $\mathrm{MHz}$ with a spinning rate of $8 \mathrm{kHz}$, using a $4 \mu \mathrm{s}(\pi / 2)$ pulse with a 2 s recycle delay; chemical shifts were referenced to $\mathrm{NH}_{4} \mathrm{Al}\left(\mathrm{SO}_{4}\right)_{2} \cdot 12 \mathrm{H}_{2} \mathrm{O}$. X-ray photoelectron spectroscopy (XPS) was performed using a VG K-Alpha photoelectron spectrometer using $\mathrm{Al} K_{\alpha}$ radiation. Surface area and pore size distribution were obtained with a Quantachrome AUTOSORB-1 analyzer using low-temperature $\mathrm{N}_{2}$ adsorption. The adsorption capacities of $n$-hexane and cyclohexane were measured at $25^{\circ} \mathrm{C}$ using a flow adsorption method. The acidic properties of the samples were obtained with a Quantachrome CHEMBET 3000 instrument using the $\mathrm{NH}_{3}$ temperature-programmed desorption (TPD) method.

\subsection{Catalytic tests}

The prepared catalysts were tested for MTG in a continuous-flow fixed-bed reactor at atmospheric pressure. The HZSM-5 catalyst (1.0 g, 20-40 mesh) was placed in the center of the stainless-steel tubular reactor and $\gamma-\mathrm{Al}_{2} \mathrm{O}_{3}(1.0 \mathrm{~g})$ was placed above it, separated by a layer of alumina balls. The weight hourly space velocity was $2.0 \mathrm{~h}^{-1}$, and the reaction temperature was $380{ }^{\circ} \mathrm{C}$. The effluent from the reactor was separated into gaseous and liquid products using ice-water.

Analysis of the gaseous products was performed using a Tianmei GC 7890F gas chromatograph equipped with an HP-PLOTQ capillary column (30 $\mathrm{m} \times 4 \mathrm{~mm})$, and the organic phase of the liquid product was analyzed using the GC 7890F gas chromatograph equipped with an OV-101 capillary column $(50 \mathrm{~m} \times 0.23 \mathrm{~mm} \times 0.50 \mu \mathrm{m})$, with quantitative analysis using PONA software. The conversion of methanol to hydrocarbon products (dimethyl ether (DME) was considered to be reactant), $X_{\mathrm{M}}$, is defined as $X_{\mathrm{M}}=(1-$ the molar percentage of methanol in the effluent/the molar percentage of methanol in the reactant) $\times 100 \%$. 


\section{Results and discussion}

\subsection{Catalyst characterization}

Figure 1 shows the XRD patterns of the HZSM-5 samples. The number of peaks and the peak positions did not change after TPAOH treatment. The peak intensities at both low $(2 \theta=$ $7.8^{\circ}$ and $\left.8.7^{\circ}\right)$ and high $\left(2 \theta=22.9^{\circ}, 23.6^{\circ}\right.$, and $\left.24.3^{\circ}\right)$ diffraction angles increased slightly. This indicates that the TPAOH treatment did not adversely affect the crystal structure, and the relative crystallinities of the modified samples increased slightly, probably as a result of changes in an unstable phase. Li et al [15] modified a ZSM-5 zeolite in a mixed alkaline aqueous solution of TPAOH and an inorganic base, $\mathrm{NaOH}$, and found that the relative crystallinity of the zeolite increased with increasing $\mathrm{TPA}^{+} / \mathrm{OH}^{-}$ratio, indicating that the TPAOH modification is controllable.

Figure 2 shows SEM images of the HZSM-5 samples before extrusion. It can be seen that the crystal morphology was more regular and the crystals were larger after TPAOH treatment. These results are contrary to some published papers $[6,7,9,10]$, which reported that the zeolite angles disappeared, the edges blurred, and the surfaces became rougher after $\mathrm{NaOH}$ treatment. These results are also different from those in another report [15], which showed that the zeolite surface became rougher with the increasing $\mathrm{TPA}^{+} / \mathrm{OH}^{-}$ratio after treatment with a mixed alkaline aqueous solution of TPAOH and $\mathrm{NaOH}$. This shows that the inorganic base, $\mathrm{NaOH}$, had a particularly strong influence on the zeolite, whereas the organic alkaline TPAOH had a more moderate influence and stabilized the zeolite structure. The TPAOH solution acts as a lye and can lead to the removal of framework silicon as well as framework aluminum. Also, acting as a template, the TPAOH solution may lead to secondary crystallization of amorphous species, non-framework silicon, and non-framework aluminum on the zeolite surface. Consequently, the relative crystallinity of the sample increased and the crystal size increased after TPAOH treatment. Huang [16] observed secondary crystallization when TS-1 was treated with TPAOH solution, and the crystal grains became more regular and some new crystal grains appeared after modification.

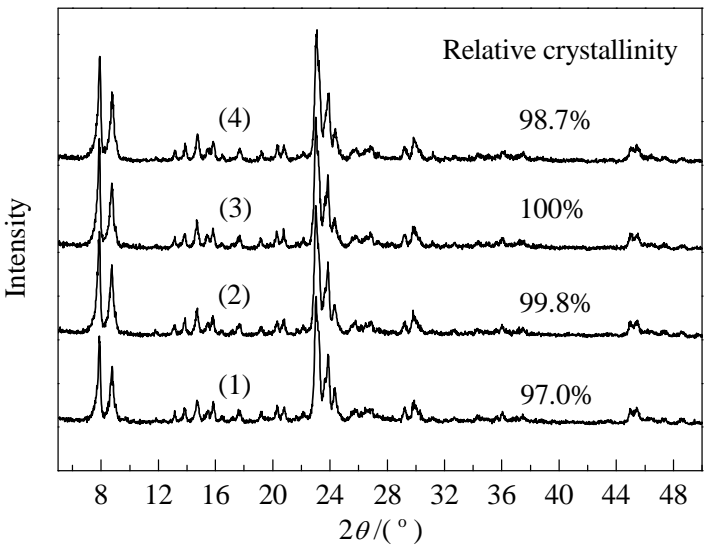

Fig. 1. XRD patterns of HZSM-5 with different TPAOH treatment time. (1) nHZ; (2) T24; (3) T48; (4) T72.

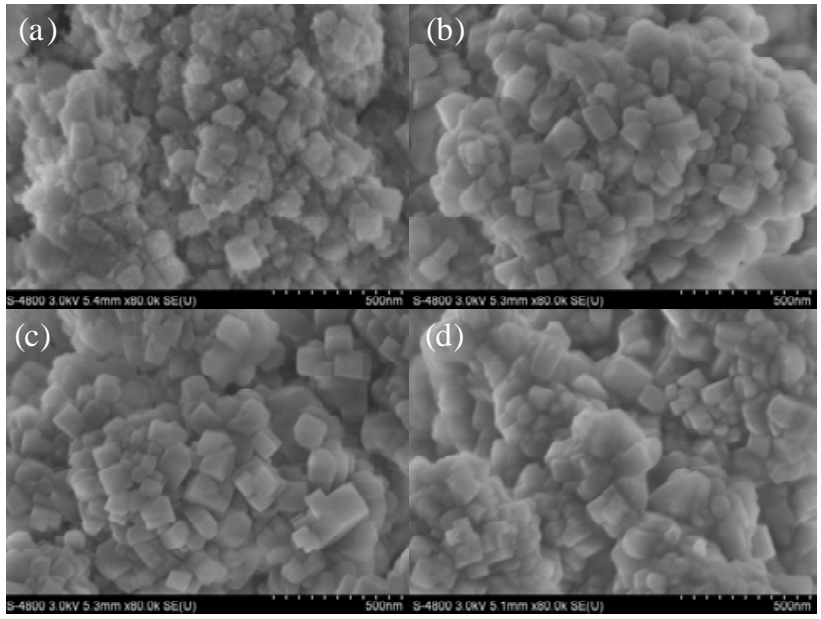

Fig. 2. SEM images of HZSM-5 with different TPAOH treatment time before extrusion. (a) HZ; (b) T24-HZ; (c) T48-HZ; (d) T72-HZ.

Figure 3(a) shows the ${ }^{27} \mathrm{Al}$ MAS NMR spectra of the HZSM-5 samples before extrusion. The spectra of all the samples are characterized by an intense and sharp signal at $\delta=54$, and a weaker and broad signal at $\delta=0$, arising from tetrahedrally coordinated framework aluminum and six-coordinated non-framework aluminum, respectively. For the HZ sample, there is a signal at $\delta=37$ attributed to five-coordinated framework aluminum. For the T24-HZ sample, the signal from five-coordinated framework aluminum decreases significantly, and the signal from non-framework aluminum increases significantly, clearly indicating removal of aluminum from the
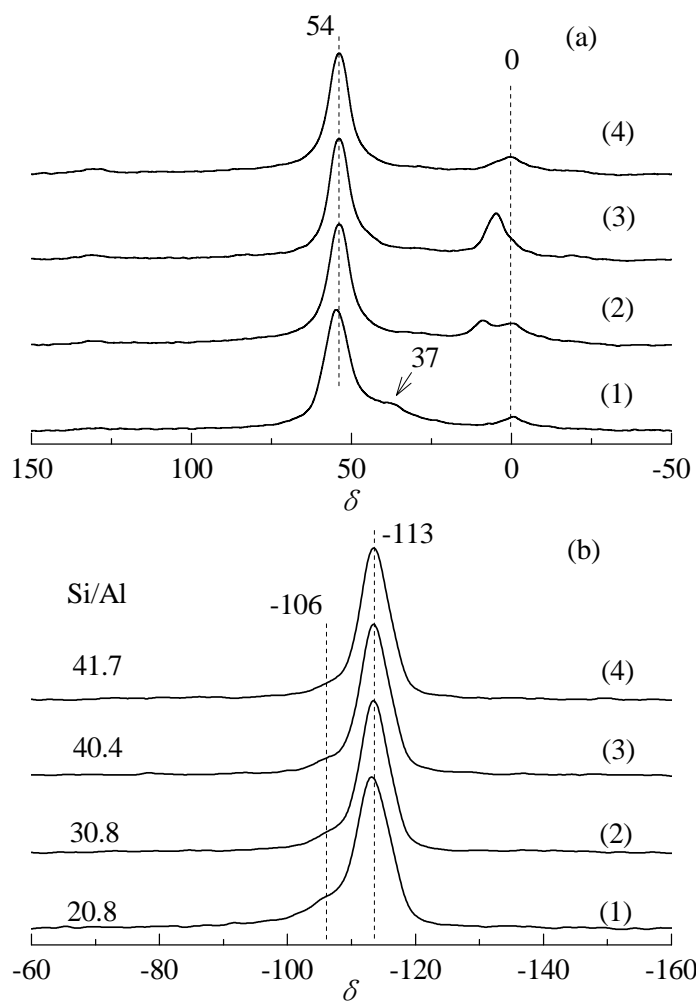

Fig. 3. ${ }^{27} \mathrm{Al}(\mathrm{a})$ and ${ }^{29} \mathrm{Si}$ (b) MAS NMR spectra of HZSM-5 with different TPAOH treatment time before extrusion. (1) HZ; (2) T24-HZ; (3) T48-HZ; (4) T72-HZ. 
lattice. For the T48-HZ sample, the signal from non-framework aluminum increases further, showing that removal of aluminum from the lattice continues to occur. For the T72-HZ sample, the signal from non-framework aluminum decreases significantly, indicating the end of dealumination and the conversion of non-framework aluminum to framework aluminum.

Figure 3(b) shows the ${ }^{29} \mathrm{Si}$ MAS NMR spectra of the samples before extrusion. All the samples have signals at $\delta=-113$ and -106 , attributed to framework $\mathrm{Si}(\mathrm{OSi})_{4}(\mathrm{Q} 4)$ and $\mathrm{Si}(\mathrm{OSi})_{3}(\mathrm{OAl})$ (Si1Al), respectively. For the T24-HZ sample, the framework $\mathrm{Si} / \mathrm{Al}$ ratio increases from 20.8 to 30.8 compared with the HZ sample as a result of removal of framework aluminum, in agreement with the ${ }^{27} \mathrm{Al}$ MAS NMR spectra. For the T48-HZ sample, the framework $\mathrm{Si} / \mathrm{Al}$ ratio further increases to 40.4 , showing that removal of aluminum from the lattice is still occurring. For the T72-HZ sample, the framework Si/Al ratio changes little compared with the T48-HZ sample, increasing from 40.4 to 41.7. Based on a combination of these results and the ${ }^{27} \mathrm{Al}$ MAS NMR spectra, it can be concluded that secondary crystallization of the zeolite occurs when the TPAOH treatment time is longer than $48 \mathrm{~h}$, resulting in migration of non-framework aluminum and non-framework silicon to the zeolite surface and their transformation into framework species. Analysis of the framework Si/Al ratio shows that the migration rate of non-framework silicon is faster than that of non-framework aluminum, especially in the treatment stage from 24 to $48 \mathrm{~h}$.

Figure 4 shows the Si $2 p$ and Al $2 p$ XPS spectra of the HZSM-5 samples before extrusion. The surface Si/Al ratios of the samples obtained from the XPS spectra are shown in Table 1. For the $\mathrm{HZ}$ sample, the surface $\mathrm{Si} / \mathrm{Al}$ ratio is 8.23 ; it is 13.2 for the T24-HZ sample, reaches a maximum, 17.9, for the T48-HZ sample, and decreases to 10.4 for the T72-HZ sample. The XPS spectra show that secondary crystallization of the zeolite does occur, making non-framework silicon migrate to the zeolite surface, resulting in an increase in the amount of framework silicon on the zeolite surface. Simultaneously, with increasing treatment time, some of the non-framework aluminum will migrate to the zeolite surface, and this is the reason for the decrease in the surface $\mathrm{Si} / \mathrm{Al}$ ratio for the T72-HZ sample. Also, the results show that the migration of non-framework silicon is much easier, and the migration rate is faster, than those of non-framework aluminum during secondary crystallization, in
Table 1

Surface $\mathrm{Si} / \mathrm{Al}$ ratios of HZSM-5 with different TPAOH treatment time before extrusion.

\begin{tabular}{lc}
\hline Sample & Surface Si/Al \\
\hline HZ & 8.2 \\
T24-HZ & 13.2 \\
T48-HZ & 17.9 \\
T72-HZ & 10.4 \\
\hline
\end{tabular}

agreement with the ${ }^{27} \mathrm{Al}$ and ${ }^{29} \mathrm{Si}$ MAS NMR results.

The pore properties of the HZSM-5 samples are shown in Table 2. The Brunauer-Emmett-Teller (BET) surface areas, micropore areas, micropore volumes, and total pore volumes of the samples all increase after TPAOH treatment, especially the micropore areas. The $\mathrm{N}_{2}$ adsorption-desorption isotherms are shown in Fig. 5. The hysteresis loops in the isotherms of the modified samples are more pronounced and migrate upwards. These results are similar to those in some previous publications [5-9], which reported that these features were attributed to desilication and formation of new mesopores in ZSM-5 zeolite treated with $\mathrm{NaOH}$ solution. Compared with $\mathrm{NaOH}$-treated samples, the changes in the hysteresis loops of the TPAOH-treated samples are less obvious, which may be the result of the moderate degree of modification caused by the TPAOH treatment, rather than new mesopore formation. However, TPAOH treatment can lead to an increase in the micropore volume, as shown by the data in Table 2 . The increase in the BET surface area is mainly caused by dissolution of framework species $[5,6]$. The micropore area increase is possibly attributable to desilication, dealumination, and secondary crystallization of the zeolite during TPAOH treatment, resulting in amorphous species becoming framework species, and clearing of the channels.

Table 2

Pore properties of HZSM- 5 with different TPAOH treatment time.

\begin{tabular}{lccccc}
\hline Sample & $\begin{array}{c}A_{\text {BET }} \\
\left(\mathrm{m}^{2} / \mathrm{g}\right)\end{array}$ & $\begin{array}{c}A_{\text {ext }^{\mathrm{a}}} \\
\left(\mathrm{m}^{2} / \mathrm{g}\right)\end{array}$ & $\begin{array}{c}A_{\text {micro }^{\mathrm{a}}} \\
\left(\mathrm{m}^{2} / \mathrm{g}\right)\end{array}$ & $\begin{array}{c}V_{\text {micro }^{\mathrm{a}}} \\
(\mathrm{ml} / \mathrm{g})\end{array}$ & $\begin{array}{c}V_{\text {total }^{\mathrm{b}}} \\
(\mathrm{ml} / \mathrm{g})\end{array}$ \\
\hline $\mathrm{nHZ}$ & 345 & 146 & 199 & 0.09 & 0.30 \\
$\mathrm{~T} 24$ & 373 & 141 & 232 & 0.10 & 0.31 \\
$\mathrm{~T} 48$ & 377 & 142 & 234 & 0.10 & 0.31 \\
T72 & 373 & 147 & 226 & 0.10 & 0.31 \\
\hline
\end{tabular}

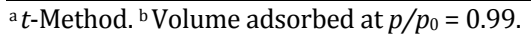

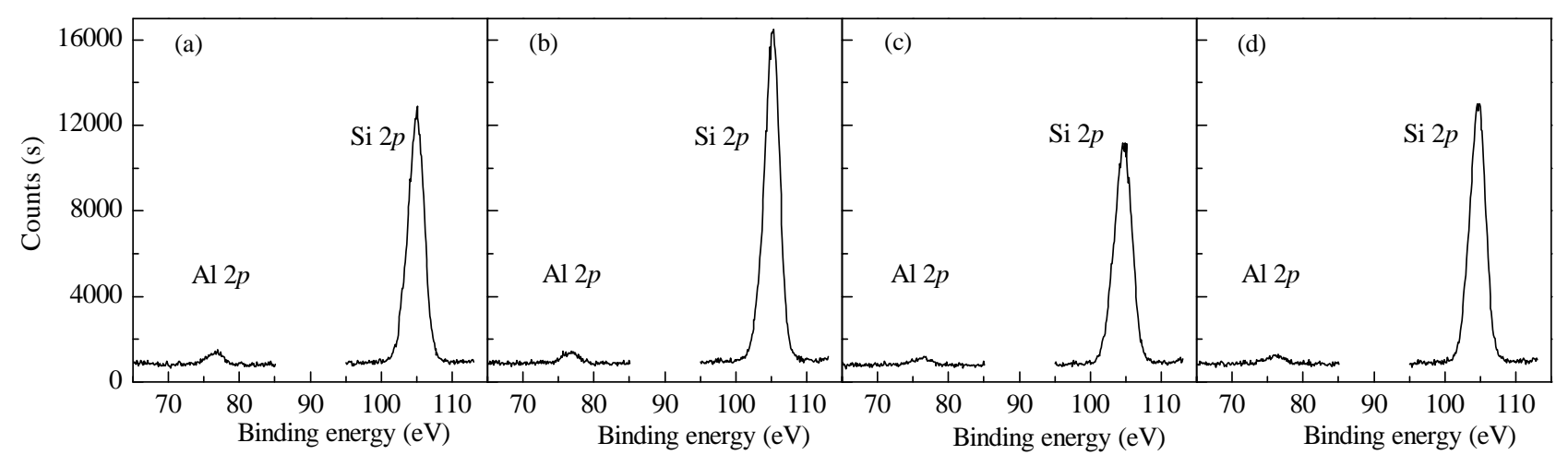

Fig. 4. Si $2 p$ and Al $2 p$ XPS spectra of HZSM-5 with different TPAOH treatment time before extrusion. (a) HZ; (b) T24-HZ; (c) T48-HZ; (d) T72-HZ. 


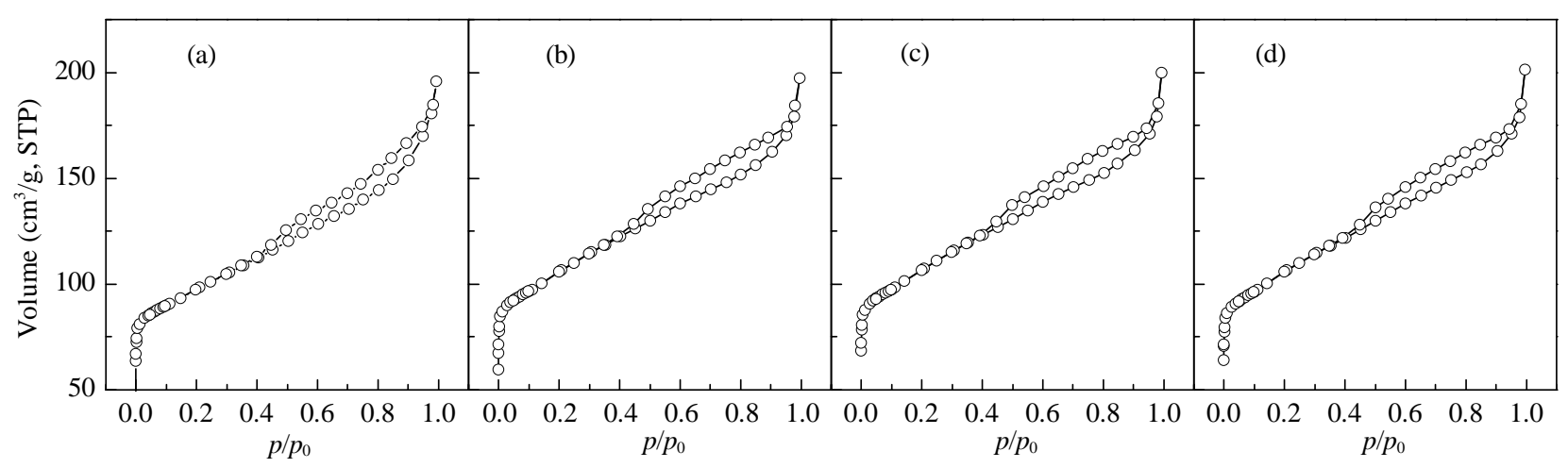

Fig. 5. $\mathrm{N}_{2}$ adsorption-desorption isotherms of HZSM-5 with different TPAOH treatment time. (a) nHZ; (b) T24; (c) T48; (d) T72.

Figure 6 shows the adsorption curves of $n$-hexane and cyclohexane on the $\mathrm{nHZ}$ and $\mathrm{T} 72$ samples. The adsorption rates and capacities of both $n$-hexane and cyclohexane on the T72 sample are higher than those on nHZ. It can be concluded that the TPAOH treatment clears the channels of the HZSM-5 zeolite and increases the pore volume; this is consistent with the $\mathrm{N}_{2}$ adsorption-desorption analysis.

Figure 7 shows the $\mathrm{NH}_{3}$-TPD curves of the HZSM-5 samples. The high-temperature peak arises from strong acid sites and the occurrence of the low-temperature peak is related to the interaction of ammonia with different weak acid sites. It can be seen that the area of the low-temperature peak decreases, whereas that of the high-temperature peak increases, after TPAOH treatment, indicating a reduction in the number of weak acid sites and an increase in the number of strong acid sites. The number of weak acid sites increases with increasing TPAOH treatment time, whereas the number of strong acid

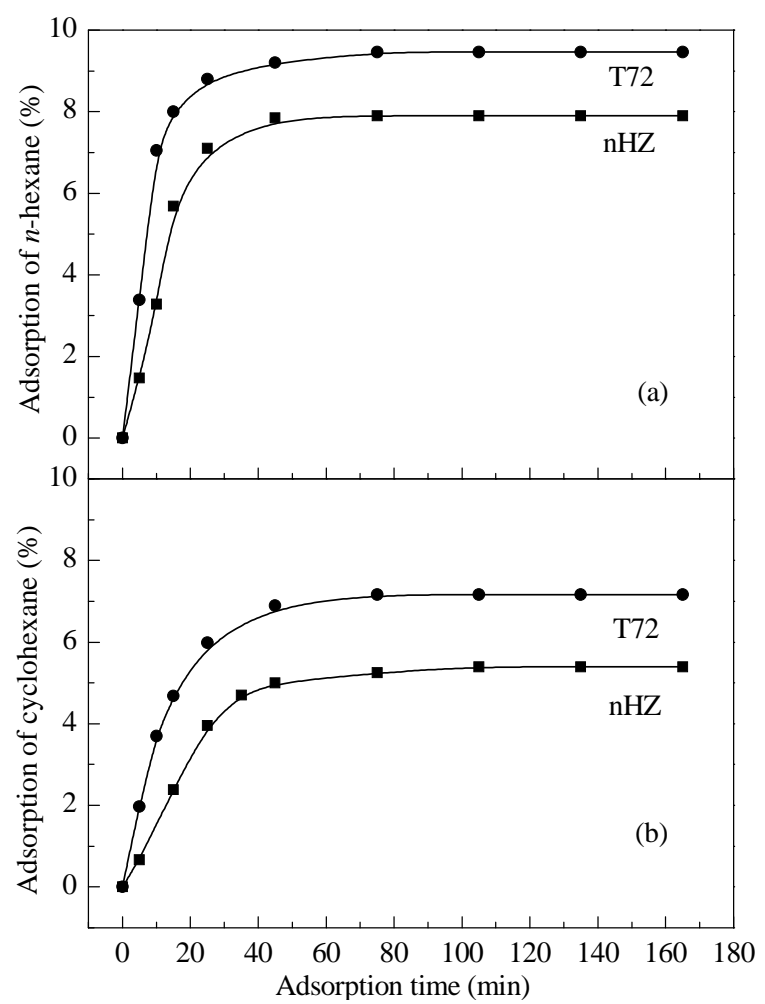

Fig. 6. Adsorption capacities of HZSM-5 before and after treatment with TPAOH for $n$-hexane(a) and cyclohexane(b). sites first decreases and then increases. The two $\mathrm{NH}_{3}$ desorption peaks shift towards lower temperatures after TPAOH treatment, showing a reduction in the strengths of the strong and weak acids. The TPAOH treatment time has less effect on the reduction in the acid strength. The change in acidity is caused by aluminum redistribution in the HZSM-5 zeolite, which may be attributed to desilication, dealumination, and secondary crystallization of the zeolite during TPAOH treatment. Presumably, the $\mathrm{Al}_{2} \mathrm{O}_{3}$ mixed with the nanocrystalline HZSM-5 during extrusion has an impact on the acidity of the HZSM-5 zeolite, leading to conversion from non-framework aluminum to framework aluminum during high-temperature calcination. However, further verification is needed.

\subsection{Catalytic testing}

Figure 8 shows the conversion of methanol to hydrocarbons as a function of time on stream for the four catalyst samples. The parent nHZ sample displays an activity above $98 \%$ within $70 \mathrm{~h}$, and deactivation is rather fast, with the activity falling below $90 \%$ after $75 \mathrm{~h}$ on stream. The lifetime of the T24 sample is significantly better, as the conversion remains above $98 \%$ for $170 \mathrm{~h}$, and deactivation is rather slow, with the activity falling below $90 \%$ after $200 \mathrm{~h}$ on stream. These effects are more pronounced for the T48 and T72 samples, i.e., the activity of the T48 sample falls below $90 \%$ after $210 \mathrm{~h}$ and the activity of the T72 sample falls below $90 \%$ after $230 \mathrm{~h}$. It is concluded that the

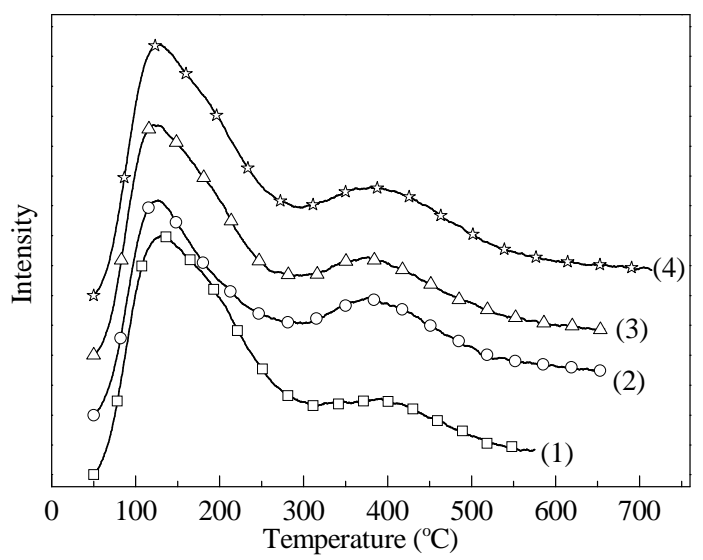

Fig. 7. $\mathrm{NH}_{3}-\mathrm{TPD}$ profiles of HZSM-5 with different TPAOH treatment time. (1) nHZ; (2) T24; (3) T48; (4) T72. 


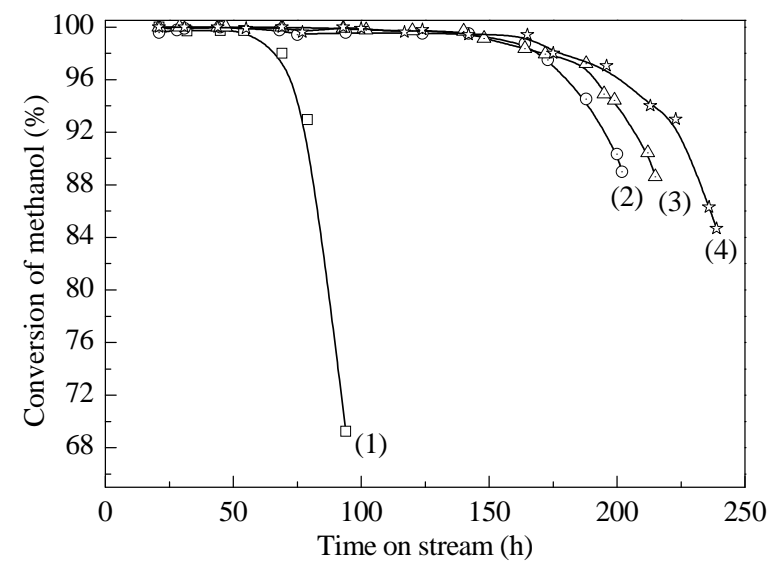

Fig. 8. Conversion of methanol/DME to hydrocarbons as a function of time on stream. (1) nHZ; (2) T24; (3) T48; (4) T72.

stability of the catalyst is significantly improved as a consequence of modification, and the lifetime of the catalyst increases with increasing TPAOH treatment time.

These results, in combination with the results of sample characterization, show that TPAOH treatment not only increases the BET surface area and exposes many more catalytic activity sites, improving adsorption and activation of reactant molecules, but also increases the micropore volume, clears the channels, and improves the diffusion capacity and coke tolerance; these are the reasons for the increased stabilities of the modified samples.

To obtain a more quantitative and precise measurement of the improvement in catalytic performance, the loosely defined concept of catalyst lifetime will be supplemented by the total conversion capacities. Based on Bjørgen's work [5], this is done by plotting the methanol conversion against the number of grams of methanol converted per gram of catalyst, and extrapolating to zero conversion, thus obtaining a value for the total capacity of the catalyst for MTG conversion until complete loss of activity; this is shown in Fig. 9. For the nHZ sample, the conversion capacity is $260 \mathrm{~g}$ (methanol)/g(catalyst). For the T24, T48, and T72 samples, the conversion capacities are 635,680 , and $750 \mathrm{~g} / \mathrm{g}$, respectively. The conversion capacity therefore

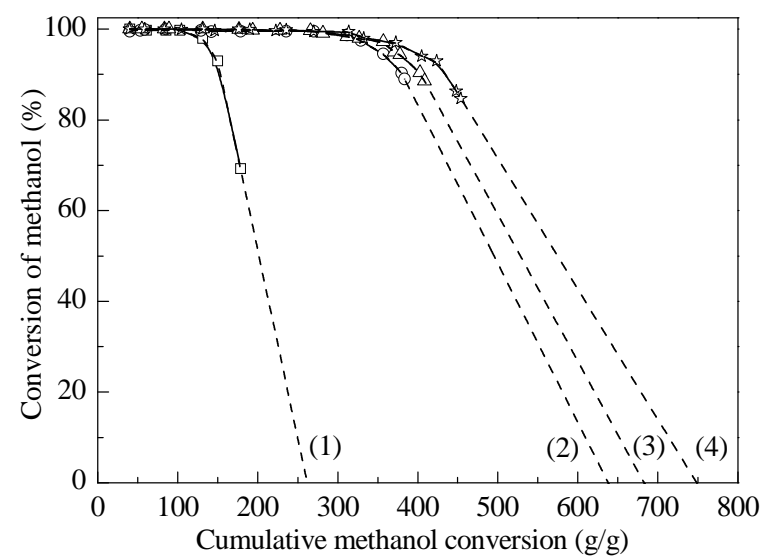

Fig. 9. Conversion of methanol plotted against the cumulative amount of methanol converted to hydrocarbons. Extrapolation to zero conversion gives the total conversion capacities of the four samples. (1) nHZ; (2) T24; (3) T48; (4) T72.
Table 3

Gaseous product distribution.

\begin{tabular}{lrrrrrrrrr}
\hline \multirow{2}{*}{ Sample } & \multicolumn{7}{c}{ Product distribution (mol\%) } & \multirow{2}{*}{$\mathrm{C}_{3} \mathrm{H}_{6} / \mathrm{C}_{2} \mathrm{H}_{4}$} \\
\cline { 2 - 8 } & $\mathrm{CH}_{4}$ & $\mathrm{C}_{2} \mathrm{H}_{4}$ & $\mathrm{C}_{2} \mathrm{H}_{6}$ & $\mathrm{C}_{3} \mathrm{H}_{6}$ & $\mathrm{C}_{3} \mathrm{H}_{8}$ & $\mathrm{C}_{4} \mathrm{H}_{8}$ & $\mathrm{C}_{4} \mathrm{H}_{10}$ & $\mathrm{C}_{5}$ & \\
\hline $\mathrm{nHZ}$ & 7.6 & 11.5 & 6.1 & 8.6 & 9.7 & 26.0 & 6.0 & 13.9 & 0.8 \\
$\mathrm{~T} 24$ & 6.7 & 8.7 & 6.6 & 8.1 & 11.1 & 28.2 & 6.6 & 15.3 & 0.9 \\
$\mathrm{~T} 48$ & 6.7 & 9.1 & 6.8 & 8.4 & 10.2 & 27.7 & 6.8 & 15.5 & 0.9 \\
$\mathrm{~T} 72$ & 6.6 & 9.0 & 7.0 & 8.2 & 11.5 & 28.5 & 6.8 & 14.8 & 0.9 \\
\hline
\end{tabular}

increases by a factor of about 3 as a result of the most severe treatment. In industry, catalytic reactions are seldom allowed to run until complete deactivation, but the calculated values show that the catalytic performance has been significantly improved by the TPAOH treatment.

Table 3 shows the gaseous product distribution, mainly light olefins and alkanes. Obviously, compared with the parent nHZ sample, the modified samples have less methane, more propane, and an increased propene/ethylene ratio in the gaseous products. Methane comes from the demethylation of aromatics and carbon precursors [17], so the more serious the carbon deposition, the more demethylation occurs, and the higher the methane formation. Some researchers have used the change in methane content as an indicator for measuring catalyst deactivation, i.e., a reduction in the methane content shows a slowing of the carbon deposition rate. We hypothesize that the diffusion of reactant and product molecules increases because the TPAOH treatment clears the channels of the HZSM-5 zeolite. Carbenium ions from propylene react with high olefins to give propane and dienes or aromatic compounds [18], as a result of hydrogen transfer reactions. The higher the propane content, the faster the hydrogen transfer reactions [19]. Hydrogen transfer is a biomolecular reaction, so it needs two acid sites with suitable and similar acid strengths. Some researchers [20] therefore consider that hydrogen transfer reactions may occur if the catalyst has a suitable space structure and active sites. After TPAOH treatment, the BET surface area and number of active sites increase, and the channels of HZSM-5 zeolite are cleared; these effects are beneficial to hydrogen transfer reactions between hydrocarbon molecules. The increase in the propene/ethane ratio is mainly caused by a decline in the ethane content, as reported by Bjørgen et al. [5], caused mainly by a decline in the rate of ethane formation via the aromatic-based hydrocarbon pool mechanism. As stated above, as the diffusivity increases and the time for which each aromatic molecule resides in the micropores is shortened, as a result of clearing the channels after TPAOH treatment, the probability of undergoing the reaction steps required for ethane formation diminishes.

Table 4 shows the liquid product distribution, mainly $\mathrm{C}_{5}-\mathrm{C}_{10}$

Table 4

Liquid product distribution.

\begin{tabular}{lccccc}
\hline \multirow{2}{*}{ Sample } & \multicolumn{5}{c}{ Product distribution (vol\%) } \\
\cline { 2 - 6 } & $i$-Paraffins & $n$-Paraffins & Olefins & Aromatics & Durene \\
\hline nHZ $^{\text {a }}$ & 31.3 & 4.1 & 9.7 & 51.7 & 4.0 \\
T24 $^{\text {b }}$ & 33.5 & 3.9 & 8.4 & 50.2 & 5.3 \\
T48 $^{\text {b }}$ & 34.4 & 3.2 & 7.8 & 50.8 & 4.3 \\
T72 $^{\text {b }}$ & 33.1 & 3.5 & 7.6 & 51.5 & 4.3 \\
\hline
\end{tabular}

a The mean value of $70 \mathrm{~h}$. ${ }^{\mathrm{b}}$ The mean value of $170 \mathrm{~h}$. 
long-chain isoparaffins, olefins, and aromatics. Compared with the parent nHZ sample, the modified samples give more isoparaffins, less olefins, and a similar amount of aromatics. The main MTG reactions are as follows [21]: (1) generation of $\mathrm{C}_{2}-\mathrm{C}_{3}$ light olefins [22]; (2) generation of $\mathrm{C}_{4}-\mathrm{C}_{6}$ mixed olefins (the majority are isoolefins) via alkylation of $\mathrm{C}_{2}-\mathrm{C}_{3}$ light olefins and oligomerization reactions between $\mathrm{C}_{2}-\mathrm{C}_{3}$ light olefins and other olefins; (3) generation of aromatics via dehydrocyclization of $\mathrm{C}_{6}-\mathrm{C}_{10}$ oligomers formed by oligomerization of linear $\mathrm{C}_{2}-\mathrm{C}_{5}$ olefins; (4) further isomerization and alkylation reactions of aromatics; and (5) hydrogen transfer reactions of isoolefins, which are not prone to oligomerization, to isoparaffins.

The main reason for the increase in the amount of isoparaffins and the decrease in the amount of olefins may be acceleration of the hydrogen transfer reactions. As mentioned above, TPAOH treatment improves the space structure and acidity of the samples, which strengthens the hydrogen transfer reaction activity. It can be seen from step (3) that aromatics are manufactured through polymerization and cyclization of light olefins, and this is associated with the pore structure and the number of strong acid sites in the zeolite. It has been reported that the generation of aromatics in MTG needs strong acidity [23,24]. As indicated by the $\mathrm{NH}_{3}$-TPD results, TPAOH treatment increases the number of strong acid sites but reduces the strong acid strength. So, there is little change in the amount of aromatics. Moreover, more durene is seen for the modified samples, which is commonly attributed to the cleared channels assisting generation and diffusion of large molecules.

\section{Conclusions}

The physical and chemical properties of a nanocrystalline ZSM-5 zeolite modified with TPAOH solution were studied; the catalytic performance of the modified zeolite in MTG reaction was also investigated. The modification led to desilication, dealumination, and secondary crystallization of the zeolite, resulting in the migration of non-framework silicon and non-framework aluminum to the zeolite surface. The structures of the modified samples were basically unchanged, but the relative crystallinities increased and the crystal morphologies were more regular. The redistribution of framework silicon and framework aluminum caused an increase in the surface $\mathrm{Si} / \mathrm{Al}$ ratio and the BET surface area, and the exposure of increased numbers of catalytic activity sites. The diffusion capacity and coke tolerance improved, which was attributed to an increase in the micropore volume and clearing of the channels. The stability of the catalyst was significantly improved, and the total conversion capacity increased by a factor of 3 as a consequence of the most severe treatment. Hydrogen transfer reactions became faster and led to more isoparaffins and less olefins in the liquid products.

\section{References}

[1] Stöcker M. Microporous Mesoporous Mater, 1999, 29: 3

[2] Zaidi H A, Pant K K. Catal Today, 2004, 96: 155

[3] Keil F J. Microporous Mesoporous Mater, 1999, 29: 49

[4] Campbell S M, Bibby D M, Coddington J M, Howe R F, Meinhold R H. J Catal, 1996, 161: 338

[5] Bjørgen M, Joensen F, Holm M S, Olsbye U, Lillerud K-P, Svelle S. Appl Catal A, 2008, 345: 43

[6] Ogura M, Shinomiya S-y, Tateno J, Nara Y, Nomura M, Kikuchi E, Matsukata M. Appl Catal A, 2001, 219: 33

[7] Suzuki T, Okuhara T. Microporous Mesoporous Mater, 2001, 43: 83

[8] Groen J C, Bach T, Ziese U, Paulaime-van Donk A M, de Jong K P, Moulijn J A, Perez-Ramirez J. J Am Chem Soc, 2005, 127: 10792

[9] Groen J C, Moulijn J A, Perez-Ramirez J. J Mater Chem, 2006, 16: 2121

[10] Ni Y M, Sun A M, Wu X L, Hai G L, Hu J L, Li T, Li G X.J Nat Gas Chem, 2011, 20: 237

[11] Xiao Q, Li Z Y, Sun X, Xiang S H. Chin J Catal (肖强, 李自运, 孙昕, 项寿鹤. 催化学报), 2005, 26: 243

[12] Mao J B, Liu M, Li P, Liu Y, Guo X W. J Fuel Chem Technol (毛璟博,

\section{Graphical Abstract}

Chin. J. Catal., 2013, 34: 1148-1158 doi: 10.1016/S1872-2067(12)60579-8

Modification of nanocrystalline HZSM-5 zeolite with tetrapropylammonium hydroxide and its catalytic performance in methanol to gasoline reaction

HE Yingping, LIU Min*, DAI Chengyi, XU Shutao, WEI Yingxu, LIU Zhongmin, GUO Xinwen*

Dalian University of Technology; Dalian Institute of Chemical Physics, Chinese Academy of Sciences
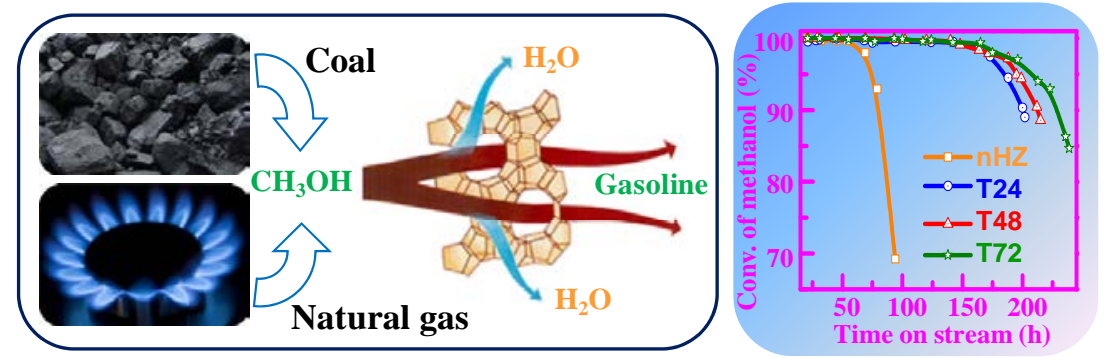

Tetrapropylammonium hydroxide treatment of the HZSM-5 zeolite improved the diffusion capacity and coke tolerance through desilication, dealumination, and secondary crystallization, reflected by the significantly increased catalyst lifetime. 
刘民，李鹏，刘阳，郭新闻. 燃料化学学报), 2008, 36: 484

[13] Xia L Z. [MS Dissertation]. Dalian: Dalian Univ Technol (夏丽贞. [硕士学位论文]. 大连: 大连理工大学], 2005

[14] Wang X Q, Wang X S, Guo X W (王学勤, 王祥生, 郭新闻). CN Patent 1240193. 2000

[15] Li S, Li Y P, Di C Y, Zhang P F, Pan R L, Dou T. J Fuel Chem Technol (李莎, 李玉平, 狄春雨, 张鹏飞, 潘瑞丽. 窦涛. 燃料化学学报), 2012, 40: 583

[16] Huang X L. [MS Dissertation]. Xiangtan: Xiangtan Univ (黄先亮. [硕 士学位论文]. 湘潭: 湘潭大学), 2008

[17] Choudhary V R, Banerjee S, Panjala D. Microporous Mesoporous Mater, 2002, 51: 203

[18] Hao X, Du M X, Hu H M, Huang Z, Hu J N. J Fuel Chem Technol (郝栩,
杜明仙, 胡惠民, 黄哲, 胡杰南. 燃料化学学报), 1995, 23: 28

[19] Zhu X X, Song Y Q, Li H B, Liu S L, Sun X D, Xu L Y. Chin J Catal (朱向 学, 宋月芹, 李宏冰, 刘盛林, 孙新德, 徐龙伢. 催化学报), 2005, 26: 111

[20] Shen Z H, Fu Y M, Jiang M, Li S Y. Chin J Catal (沈志虹, 付玉梅, 蒋 明, 李淑云. 催化学报), 2004, 25: 227

[21] Gu B E, Wu Z X. Introduction to Industrial Catalysis. Beijing: Higher Edu Press (顾伯鄂, 吴震霄. 工业催化过程导论. 北京; 高等教育 出版社), 1990.138

[22] Blaszkowski S R, Van Santen R A. J Am Chem Soc, 1997, 119: 5020

[23] Zhu J H. Chin J Catal (朱建华. 催化学报), 1993, 14: 294

[24] Wang J Y, Li W H, Hu J X. J Fuel Chem Technol (王金英, 李文怀, 胡 津仙. 燃料化学学报), 2009, 37: 607

\title{
四丙基氢氧化铵改性纳米HZSM-5分子篮及其在甲醇制汽油中的催化性能
}

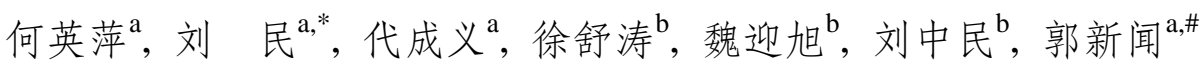 \\ ${ }^{\mathrm{a}}$ 大连理工大学化工学院催化化学与工程系, 精细化工国家重点实验室, 辽宁大连116024 \\ b 中国科学院大连化学物理研究所, 辽宁大连 116023
}

\begin{abstract}
摘要: 采用四丙基氢氧化铵(TPAOH)溶液对纳米ZSM-5分子篮进行改性, 运用X射线衍射、扫描电镜、 ${ }^{27} \mathrm{Al}$ 和 ${ }^{29} \mathrm{Si}$ 固体核磁、X射 线光电子能谱、 $\mathrm{N}_{2}$ 物理吸附脱附法和 $\mathrm{NH}_{3}$ 程序升温脱附等手段对所制样品进行了表征, 并评价了其催化甲醇制汽油反应性能. 结 果表明, 改性后的HZSM-5相对结晶度增加, 晶体形貌更加规整, 表面硅铝比增加, 比表面积和微孔表面积增大, 强酸位酸量增 多. 同时, TPAOH改性不仅可以使分子筱脱硅脱铝，而且伴有二次晶化补硅补铝，改变了分子篮的硅铝分布. 改性的HZSM-5在 甲醇制汽油反应中的稳定性大幅度提高, 其寿命由 $70 \mathrm{~h}$ 增至 $170 \mathrm{~h}$ 以上, 随着TPAOH处理时间的增加, 催化剂寿命增加, 氢转移 反应加快, 导致油相产品中异构烷烃增多, 烯烃减少.
\end{abstract}

关键词: 纳米HZSM-5; 分子篮; 四丙基氢氧化铵; 甲醇制汽油

收稿日期: 2012-11-30. 接受日期: 2013-03-18. 出版日期: 2013-06-20.

“通讯联系人. 电话/传真: (0411)84986134; 电子信箱: lium@dlut.edu.cn

\#通讯联系人. 电话/传真: (0411)84986133; 电子信箱: guoxw@dlut.edu.cn

基金来源：新世纪优秀人才支持计划(NCET-04-0268); 教育部111计划工程.

本文的英文电子版由Elsevier出版社在ScienceDirect上出版(http://www.sciencedirect.com/science/journal/18722067).

\section{1. 前言}

甲醇制汽油(MTG)工艺 ${ }^{[1 \sim 3]}$ 由Mobil公司于1976年开 发, 它主要以煤或天然气作原料, 经合成气制甲醇, 再 将粗甲醇转化为高辛烷值高品质汽油. 随着世界石油资 源的日益贾乏和国内甲醇产能的日益过剩, 甲醇作为新 的化石原料来源已成为一种趋势; 而且由甲醇制得的汽 油不含硫和氯等组分, 抗爆震性好.

ZSM-5分子篮是MTG技术的关键，其骨架中含有 两种相互交叉的孔道体系: 椭圆形十元环直孔道和圆形 之字形弯曲孔道, 其孔径分别约为 $0.51 \mathrm{~nm} \times 0.55 \mathrm{~nm}$ 和 $0.53 \mathrm{~nm} \times 0.56 \mathrm{~nm}$. 因此, ZSM-5能使汽油沸点范围内的 烃分子通过, 而临界尺寸大于均四甲苯的分子很难通 过, 使MTG反应选择性较高. 但由于母体HZSM-5的酸 性强, 反应过程中极易发生积炭失活 ${ }^{[4]}$, 需要对其改性 以制得性能更加优良的催化剂.

近年来, 碱改性法备受关注, 即选择性地从分子篮
骨架上脱去硅原子，从而引入介孔或大孔，使得分子篮 的扩散能力和催化裂化能力增加. Bjørgen等 ${ }^{[5]}$ 发现, 经 $\mathrm{NaOH}$ 改性的ZSM-5分子篎比表面积增加, 骨架Si/Al比 降低, 有中孔产生, 稳定性增加, 催化MTG反应可生成 更多的芳烃和烷烃. Ogura等 ${ }^{[6]}$ 和Suzuki等 ${ }^{[7]}$ 使用 $\mathrm{NaOH}$ 处理具有MFI结构的ZSM-5分子䇻, 发现处理后样品的 吸附曲线和孔分布发生变化, 其催化活性明显提高. Groen等 ${ }^{[8,9]}$ 采用碱处理选择性地从分子篮骨架中脱除 $\mathrm{Si}$ 元素, 致使分子篮结构改变. $\mathrm{Ni}$ 等 ${ }^{[10]}$ 采用 $\mathrm{NaOH}$ 对 ZSM-5分子篮进行处理, 使分子篮产生中孔, 配合Zn浸 渍改性, 在MTG反应中可以显著提高催化剂的稳定性 和液态烃的收率. 肖强等 ${ }^{[11]}$ 采用 $\mathrm{NaOH}$ 处理含有模板剂 的丝光沸石, 发现其催化异丁烯的转化率提高了 $13 \%$. 比较而言, 有机碱改性的速率较温和且具有可控性, 目 前多用于TS-1分子篮的改性. 毛璟博等 ${ }^{[12]}$ 采用四丙基 氢氧化铵(TPAOH)对微米TS-1进行改性, 发现改性后的 TS-1基本结构没有明显变化, 但在内部出现蚀刻现象, 
其催化苯酚羟基化和丁酮氨氧化性能明显提高. 夏丽 贞 ${ }^{[13]}$ 采用TPAOH等有机碱对纳米TS-1进行改性, 发现 改性后催化剂在甲乙酮氨氧化反应中的重复使用性能 显著提高. 目前, 采用有机碱处理ZSM-5分子篮还鲜见 报道. 本文使用 TPAOH溶液对纳米ZSM-5分子笁进行 改性, 考察了处理时间对HZSM-5分子篮的物化性质及 其催化MTG反应性能的影响.

\section{2. 实验部分}

\section{1. 催化剂的制备}

按照专利 ${ }^{[14]}$ 方法合成纳米 NaZSM-5 分子篮 $\left(\mathrm{SiO}_{2} / \mathrm{Al}_{2} \mathrm{O}_{3}\right.$ 摩尔比为 $\left.26,70 \sim 100 \mathrm{~nm}\right)$, 再将其与 $\mathrm{TPAOH}$ 溶液 $(0.1 \mathrm{~mol} / \mathrm{L})$ 混合, 置于高压釜中, 在 $170{ }^{\circ} \mathrm{C}$ 下分别处 理 24,48 和 $72 \mathrm{~h}$, 经过滤、烘干和 $540^{\circ} \mathrm{C}$ 焙烧后, 得到改 性的钠型ZSM-5分子篎样品. 将未处理的纳米ZSM-5或 改性后的钠型分子笁放入硝酸铵水溶液 $(0.4 \mathrm{~mol} / \mathrm{L})$ 中, 按固液比 $1: 10$ 在 $75^{\circ} \mathrm{C}$ 下交换 3 次, 每次 $2 \mathrm{~h}$, 用去离子水 洗涤至中性, 抽滤, 在 $100{ }^{\circ} \mathrm{C}$ 烘干, $540{ }^{\circ} \mathrm{C}$ 焙烧 $4 \mathrm{~h}$, 制得 TPAOH改性的氢型纳米ZSM-5 分子篎样品, 分别记为 HZ (未处理), T24-HZ (处理24h), T48-HZ (处理48 h) 和 T72-HZ (处理 $72 \mathrm{~h}$ ). 将氢型分子篮与拟薄水铝石混合 (干基质量比为 $4: 1$ ), 加入适量田菁粉, 再加入稀硝酸溶 液(体积分数 $10 \%$ ), 摚拌混合均匀, 挤条成型, 室温阴 干, 于 $100^{\circ} \mathrm{C}$ 烘干, $540^{\circ} \mathrm{C}$ 焙烧 $4 \mathrm{~h}$, 得到TPAOH改性纳 米HZSM-5分子篮样品, 分别记为nHZ, T24, T48和 T72.

\section{2. 催化剂的表征}

$X$ 射线衍射 (XRD) 表征在日本 Rigaku 公司 $\mathrm{D} / \mathrm{max}-2400$ 型X射线粉末衍射仪上进行, $\mathrm{Cu} K_{\alpha}$ 辐射, 扫 描范围 $2 \theta=5^{\circ} \sim 50^{\circ}$, 扫描步幅 $0.02^{\circ}$. 催化剂形貌在日本 JEOL公司JSM-5600 LV型扫描电子显微镜(SEM)上观 测, 电压 $20 \mathrm{kV} .{ }^{27} \mathrm{Al}$ 和 ${ }^{29} \mathrm{Si}$ 固体核磁(MAS NMR)谱在 Bruker Avance III 600型核磁共振波谱仪上测量, 使用4 mm MAS探头. ${ }^{27} \mathrm{Al}$ MAS NMR谱的化学位移以三甲基 硅丙磺酸钠(DSS)为外标, 共振频率156.4 MHz, 样品转 速 $12 \mathrm{kHz}$, 脉冲宽度 $0.75 \mu \mathrm{s}(\pi / 8)$, 采样延迟 $2 \mathrm{~s} ;{ }^{29} \mathrm{Si}$ MAS $\mathrm{NMR}$ 谱的化学位移以 $\left(\mathrm{NH}_{4}\right) \mathrm{Al}\left(\mathrm{SO}_{4}\right)_{2} \cdot 12 \mathrm{H}_{2} \mathrm{O}$ 为外标, 共 振频率 $119.2 \mathrm{MHz}$, 样品转速 $8 \mathrm{kHz}$, 脉冲宽度 $4 \mu \mathrm{s}(\pi / 2)$, 采样延迟 $4 \mathrm{~s}$. X射线光电子能谱(XPS)分析采用英国VG 公司 K-Alpha型 X射线光电子能谱仪测定, 激发源为 $\mathrm{Al}$ $K_{\alpha} . \mathrm{N}_{2}$ 物理吸附脱附实验使用美国 Quantachrome公司 AUTOSORB-1型物理吸附仪, 测试前先在 $350^{\circ} \mathrm{C}$ 抽真 空, 孔分布及孔体积由H-K方程计算得到, 比表面积由
BET方法求得. 以正己烷和环已烷为吸附质, 在 $25^{\circ} \mathrm{C}$ 采 用连续流动法测定样品的吸附量. $\mathrm{NH}_{3}$ 程序升温脱附 $\left(\mathrm{NH}_{3}-\mathrm{TPD}\right)$ 表征在美国 Quantachrome 公司 CHEMBET 3000 型化学吸附分析仪上进行, $\mathrm{He}$ 为载气, 升温速率 10 ${ }^{\circ} \mathrm{C} / \mathrm{min}$.

\section{3. 催化剂的评价}

MTG 反应在连续流动常压固定床上进行, 将 $1 \mathrm{~g}$ HZSM-5样品(20 40目)置入长 $40 \mathrm{~cm}$ 、内径 $0.8 \mathrm{~cm}$ 的不锈 钢管式反应器中部(恒温段), 填充一层惰性瓷球, 再置 入 $1 \mathrm{~g}$ 的 $\gamma-\mathrm{Al}_{2} \mathrm{O}_{3}$ 催化剂, 反应器其它非恒温段填充惰性 瓷球, 液体原料甲醇由双柱塞百连续注入反应器, 甲醇 重时空速为 $2.0 \mathrm{~h}^{-1}$, 反应温度为 $380^{\circ} \mathrm{C}$. 产物经冰水气 液分离, 液相产物又经分液漏斗分为水相和油相, 气相 产物分析采用天美GC 7890F型气相色谱仪, HP-PLOTQ 毛细柱 (30 m $\times 4 \mathrm{~mm})$, FID检测器; 油相产物分析采用 天美GC 7890F型气相色谱仪, OV-101毛细管柱 $(50 \mathrm{~m} \times$ $0.23 \mathrm{~mm} \times 0.50 \mu \mathrm{m}), \quad F I D$ 检测器, 色谱数据用石科院 PONA软件分析计算, 得到产物的芳烃、烯烃、正构烷 烃、异构烷烃及环烷烃的体积含量. 甲醇转化率(二甲醚 和甲醇一起被认为是反应物) $X_{\mathrm{M}}$ 计算式为: $X_{\mathrm{M}}=(1-$ 反 应产物中甲醇的摩尔分数/反应进料中甲醇的摩尔分数) $\times 100 \%$.

\section{3. 结果与讨论}

\subsection{HZSM-5分子篮的表征}

图1为改性前后HZSM-5的XRD谱. 可以看出, 改性 后的样品在 $2 \theta=7.8^{\circ}, 8.7^{\circ}, 22.9^{\circ}, 23.6^{\circ}$ 和 $24.3^{\circ}$ 处均有特 征峰出现, 且衍射峰相对强度均有所增加, 说明 TPAOH处理并未破坏ZSM-5的MFI晶体结构, 而可能使 其中一些不稳定相发生了转变, 导致相对结晶度有所增 加. 李莎等 ${ }^{[15]}$ 采用 TPAOH/NaOH混合碱体系对 ZSM-5 进行改性, 发现随着 $\mathrm{TPA}^{+} / \mathrm{OH}^{-}$的增大, 分子篮的相对 结晶度逐渐增加, 说明TPAOH对分子篎具有可调控性.

图2为改性前后HZSM-5的SEM照片. 可以看出, 经 TPAOH处理后的HZSM-5晶粒形貌更加规整, 并且颗粒 有增大趋势. 但文献报道 ${ }^{[6,7,9,10]}$, 经 $\mathrm{NaOH}$ 溶液处理过的 分子篮棱角消失, 边缘模糊, 表面粗粘, 与本文结果不 同, 也与采用 $\mathrm{TPAOH} / \mathrm{NaOH}$ 混合碱体系处理ZSM-5不 尽相同, 但是李莎等 ${ }^{[15]}$ 发现, 随着 $\mathrm{TPA}^{+} / \mathrm{OH}^{-}$比值减小, 分子篮表面的粗糙程度加剧, 说明无机碱 $\mathrm{NaOH}$ 对分子 篮的作用较强, 有机碱TPAOH的作用较温和, 且对分 子篮结构的稳定化能力较强. TPAOH处理后的分子篮 
晶粒增大且变得规整, 可能是由于 $\mathrm{TPAOH}$ 作为碱液, 在处理过程中, 使分子篎中的骨架硅物种脱除, 同时也 使得部分铝物种脱除; 但TPAOH又是一种模板剂, 因 此脱除下来的硅物种和铝物种以及原来表面的无定形 物种还会在分子節表面发生二次晶化, 致使晶粒增大且 更加规整. 黄先亮 ${ }^{[16]}$ 也发现, 采用有机碱TPAOH对 TS-1进行处理, 会发生二次晶化过程, 晶粒结构变得完 整且会出现新的晶粒.

图3为改性前后HZSM-5的 ${ }^{27} \mathrm{Al}$ 和 ${ }^{29} \mathrm{Si}$ MAS NMR谱. 由图3(a)可见, 样品在 $\delta=54$ 有一个尖锐而强的峰, 在 $\delta=0$ 附近有一个宽而较弱的峰, 分别归属于分子篮的四 配位骨架铝和六配位非骨架铝. 对于未处理的HZSM-5 样品, 在 $\delta=37$ 还有较明显的信号峰, 归属于五配位的 骨架铝. 经过TPAOH处理 $24 \mathrm{~h}$ 后的样品, 五配位骨架铝 信号峰的相对强度明显降低, 但非骨架铝信号峰的明显 增加, 表明经过TPAOH处理后, HZSM-5样品发生了较 明显的脱铝. 随着处理时间增加到 $48 \mathrm{~h}$, 非骨架铝信号 峰相对强度进一步增加, 表明脱铝过程继续发生; 至72 $h$, 非骨架铝信号峰相对强度反而明显降低, 这预示着 脱铝过程结束, 同时部分非骨架铝有可能向骨架铝发生 了转变. 如图3(b)所示, 所有样品的 ${ }^{29} \mathrm{Si}$ MAS NMR谱均 在 $\delta=-113$ 和 -106 处出现共振峰, 分别归属于分子篮骨 架 $\mathrm{Si}(\mathrm{OSi})_{4}(\mathrm{Q} 4)$ 和 $\mathrm{Si}(\mathrm{OSi})_{3}(\mathrm{OAl})(\mathrm{Si} 1 \mathrm{Al})$. 经过 TPAOH处 理 $24 \mathrm{~h}$, 由硅谱计算样品的骨架 $\mathrm{Si} / \mathrm{Al}$ 比从20.8增至 30.8 , 说明有骨架铝脱除, 与 ${ }^{27} \mathrm{Al}$ MAS NMR谱结果一致. 随 着处理时间增大到 $48 \mathrm{~h}, \mathrm{Si} / \mathrm{Al}$ 比进一步增加到 40.4 , 说 明脱铝仍较明显; 至72 h, Si/Al比略增至41.7. 结合 ${ }^{27} \mathrm{Al}$ MAS NMR结果可认为, $48 \mathrm{~h}$ 后脱铝过程结束, 同时可能 伴有二次晶化过程, 脱除下来的非骨架硅和非骨架铝可 以重新迁移到分子䇻骨架. 基于骨架 $\mathrm{Si} / \mathrm{Al}$ 比持续增加 可以看出, 二次晶化过程中脱除下来的硅迁移到分子篮 骨架的速度快于非骨架铝迁移到分子䇻骨架的, 特别是 在24 48 h的处理阶段.

采用XPS表征可得到分子篮表面上 $\mathrm{Si} 2 p$ 和 $\mathrm{Al} 2 p$ 的 XPS 谱峰面积, 结果见图4. 由此算得的分子篮表面 $\mathrm{Si} / \mathrm{Al}$ 比示于表1. 可以看出, HZSM-5表面硅铝比为8.23, 经TPAOH处理后升高, 至48 h达最高, 然后又降低. 结 果表明, TPAOH处理过程中确可发生二次晶化, 使得脱 除下来的硅迁移到分子篮外表面, 导致表面硅含量增 加. 随着处理时间的延长, 脱除下来的少量非骨架铝也 迁移到分子篮表面, 因此表面 $\mathrm{Si} / \mathrm{Al}$ 比呈现下降趋势. 这 也进一步说明了二次晶化过程中非骨架硅较易发生迁
移, 并且迁移速度快于非骨架铝, 与 ${ }^{27} \mathrm{Al}$ 和 ${ }^{29} \mathrm{Si} \mathrm{MAS}$ NMR结果一致.

表 2 为各分子篮样品的孔结构性质. 可以看出, TPAOH处理以后的分子篮比表面积、微孔表面积、微 孔体积和总孔体积均有所增加, 特别是微孔表面积.

图5为TPAOH改性前后分子篮样品的 $\mathrm{N}_{2}$ 吸附-脱附 等温线. 由图可见, 改性后HZSM-5的滞后环稍有增大, 并且向上迁移, 与文献[5 9]中采用 $\mathrm{NaOH}$ 处理ZSM-5的 结果类似, 可认为是分子篮骨架脱硅和产生新的介孔所 致. 而 TPAOH处理后分子篮滞后环的变化不太显著, 可能是由于 $\mathrm{TPAOH}$ 处理比较温和, 未能产生较为明显 的介孔, 但仍能说明改性后的HZSM-5微孔体积有所增 加, 与表2结果一致. 比表面积的增加主要是由于骨架 物种的脱除 ${ }^{[5,6]}$; 微孔体积的略有增加是由于骨架脱硅 脱铝所致, 还可能是因为原本孔道内的无定形物种在二 次晶化过程中转化为了骨架物种, 疏通了分子篮的孔 道.

图6为 $\mathrm{nHZ}$ 和 $\mathrm{T} 72$ 的正己烷和环己烷的吸附曲线. 经 过TPAOH处理 $72 \mathrm{~h}$ 以后, HZSM-5的正己烷和环己烷的 吸附量和吸附速率均增加, 说明 TPAOH处理疏通了分 子篮的孔道, 使分子篮孔体积变大. 这与 $\mathrm{N}_{2}$ 物理吸附分 析结果一致.

图7为改性前后 HZSM-5的 $\mathrm{NH}_{3}-\mathrm{TPD}$ 曲线. 图中低 温和高温 $\mathrm{NH}_{3}$ 脱附峰分别对应于催化剂表面的弱酸位和 强酸位. 可以看出, 经TPAOH处理后, HZSM-5分子篎 的低温脱附峰面积减小, 高温脱附峰面积增大, 表明弱 酸位的酸量降低, 强酸位的酸量增加. 另外, 随着 TPAOH处理时间的延长, 弱酸位的酸量增加, 强酸位 的酸量先减少后增加. 经TPAOH处理后, 样品的两个 $\mathrm{NH}_{3}$ 脱附峰的温度均向低温方向移动, 说明分子篎的强 酸位和弱酸位的酸强度都有所减弱, 但是处理时间对样 品酸强度的影响不大. TPAOH处理过程中, 分子篮发生 脱硅脱铝, 并且伴随二次晶化, Al在HZSM-5分子篮上 发生重新分布, 导致酸量和酸强度的不同变化. 另外, 由于分子篮挤条成型过程中加入了拟薄水铝石, 焙烧过 程中可能有部分铝物种进入骨架, 对分子篮的酸性产生 影响, 但还需进一步验证.

\subsection{HZSM-5 在MTG反应中的催化性能}

图8是改性前后HZSM-5分子篮上MTG反应的甲醇 转化率随时间的变化. 由图可见, 在反应 $70 \mathrm{~h}$ 内, $\mathrm{nHZ}$ 样 品上甲醇转化率保持在 $98 \%$ 以上, 随后迅速下降, 而经 过TPAOH处理的HZSM- 5 上 $98 \%$ 以上的甲醇转化率能保 
持 $170 \mathrm{~h}$ ，然后才慢慢下降； T24在反应 $200 \mathrm{~h}$ 后，甲醇转 化率降到 $90 \%$ 以下，与母体相比，催化剂的稳定性得到 极大改善. 此外, T48在反应约 $210 \mathrm{~h}$, 甲醇转化率降到 90\%以下，T72在反应约 $230 \mathrm{~h}$ 降到 $90 \%$ 以下，可知，随着 TPAOH处理时间的增加, 催化剂寿命延长.

结合上文表征可知，TPAOH处理增加了分子篮的 比表面积, 更多催化活性位的暴露有利于原料分子的吸 附和活化; 微孔体积增加, 孔道疏通, 减小了分子的扩 散阻力, 提高了催化剂的扩散能力和容炭能力. 这是催 化剂稳定性随着TPAOH处理时间的增加而增加的原因.

为了定量改性前后HZSM-5催化性能的改善情况, 可根据甲醇转化率随时间变化的趋势图推算甲醇转化 率随着已转化甲醇质量的变化趋势 ${ }^{[5]}$, 结果见图9. 由此 图可得到催化剂完全失活前, 即甲醇转化率为零之前已 经转化的甲醇质量, 以此来定量反映催化剂的催化能 力. 对于 $n H Z$, 甲醇转化能力约为 $260 \mathrm{~g}$ (甲醇) $/ \mathrm{g}$ (催化 剂), T24的约为 $635 \mathrm{~g} / \mathrm{g}, \mathrm{T} 48$ 和 T72 的分别约为 680 和 750 $\mathrm{g} / \mathrm{g}$. 可见, 经 $\mathrm{TPAOH}$ 处理 $72 \mathrm{~h}$, 所得样品催化甲醇转化 能力可提高到原来的3倍. 虽然工业应用中很少有直到 催化剂完全失活才停止反应的情况, 但是这种推算仍然 能说明经TPAOH改性后催化剂催化能力得到了显著改 善.

各样品上MTG反应的气相产物含量列于表 3 . 可以 看出, 经 TPAOH处理后, 所得样品上气相产物较为明 显的变化是甲烷减少, 丙烷增多, 丙烯/乙烯比增加, 但 处理时间的影响不明显. 甲烷主要是由芳烃和积炭前驱 体通过脱甲基反应生成 ${ }^{[17]}$, 催化剂的积炭程度越严重, 脱甲基反应越明显，生成的甲烷越多. 人们常用甲烷含 量的变化来反映催化剂的失活情况, 气相产物中甲烷含 量减少, 说明积炭速率降低. 这是因为TPAOH改性疏 通了分子篮的孔道，有利于反应物和产物分子的扩散; 丙烯生成的碳正离子与高碳烯烃反应得到丙烷和二烯 烃或芳烃 ${ }^{[18]}$, 这与氢转移反应相关, 丙烷含量增多, 说 明氢转移反应加快 ${ }^{[19]}$. 氢转移反应是双分子反应, 需要 两个酸强度合适且相近的活性中心才能进行, 因此, 有 人认为 ${ }^{[20]}$ 催化剂必须具有合适的空间结构和活性中心 才能发生氢转移反应. 经过TPAOH处理以后, HZSM-5 分子篮的比表面积增大, 表面的活性中心增多, 而且分
子篎孔道疏通, 强酸酸量也有所增加, 因而有利于烃分 子间的氢转移反应; 丙烯/乙烯比增加主要是由于乙烯 的减少所致, 与Bjørgen等 ${ }^{[5]}$ 的结果一致. 这主要是由于 芳烃通过烃池机理生成乙烯的速率降低, 因为 $\mathrm{TPAOH}$ 处理疏通了分子篮的孔道, 使得分子的扩散速率加快, 因此芳烃的停留时间变短, 生成的乙烯减少.

油相产物主要为 $\mathrm{C}_{5} \sim \mathrm{C}_{10}$ 长链异构烷烃、烯烃和芳烃. 如表4所示, 经TPAOH处理的样品上异构烷烃略有增 加, 烯烃略有减少, 芳烃变化不大. MTG主要发生如下 反应 ${ }^{[21]}$ : (1)首先生成 $\mathrm{C}_{2} \sim \mathrm{C}_{3}$ 低碳烯烃 ${ }^{[22]}$; (2) $\mathrm{C}_{2} \sim \mathrm{C}_{3}$ 低碳 烯烃通过烷基化反应以及与其它烯烃的齐聚反应生成 $\mathrm{C}_{4} \sim \mathrm{C}_{6}$ 混合烯烃(大部分为异构烯烃); (3)线性 $\mathrm{C}_{2} \sim \mathrm{C}_{5}$ 烯烃 齐聚生成 $\mathrm{C}_{6} \sim \mathrm{C}_{10}$ 齐聚物, 经脱氢环化生成芳烃; (4)芳烃 可进一步异构化和烷基化; (5)异构烯烃不易齐聚, 在芳 构化反应中可经氢转移生成异构烷烃. 油相催化产品中 的异构烷烃略有增加, 烯烃略有减少, 主要原因可能是 步骤(5)中的氢转移反应加快, 这与前述的氢转移反应 加快原因一致，说明TPAOH改性调变了分子篮的空间 结构和酸分布, 使催化剂的氢转移活性增强. 芳烃主要 是通过步骤(3)即低碳烯烃聚合环化生成, 主要与催化 剂的孔道结构和强酸中心的量有关. 研究表明, MTG反 应中芳烃的生成需要较强的酸性中心 ${ }^{[23,24]}$, 改性后分子 篮强酸酸量稍有增加, 但酸强度有所降低, 因此芳烃变 化不大. 另外, 孔道的疏通有利于大分子产物的生成和 扩散, 导致产品中均四甲苯的含量增加.

\section{4. 结论}

采用TPAOH对纳米ZSM-5分子篮进行改性, 发现 处理过程中分子篮会发生脱硅脱铝, 并且伴有二次晶 化, 以致非骨架硅铝会重新迁移到分子篮表面, 其中非 骨架硅的迁移速度快于非骨架铝. 改性后的HZSM-5相 对结晶度增加, 且晶粒形貌更加规整; 骨架硅铝的重新 分布导致表面硅铝比增加，比表面积显著增大，更多的 活性中心暴露出来; 微孔体积增加, 孔道疏通, 使得催 化剂的扩散能力和容炭能力提高. 改性后的HZSM-5分 子篎在MTG反应中稳定性大幅度增加, 甲醇转化能力 提高至原来的3倍, 油相产品中异构烷烃增多, 烯烃减 少, 芳烃的量几乎不变. 